\title{
Code- Switching as a teaching strategy: Implication for English Language teaching and learning in a multilingual society.
}

\author{
Olagunju Robert Modupeola \\ (General Studies Department/ Osun State Polytechnic,Iree, Nigeria)
}

\begin{abstract}
Due to the alarming decline in the proficiency rate of learners as well as speakers of English Language and the recourse of many language facilitators to the use of Code switch strategy for language instructions, this paper sets out to examine critically the Code switch phenomenon to ascertain its importance to the teaching and learning of English language and indeed other subjects in Nigeria. It is discovered that Code switching is important to the teaching of language at the foundation level to draw the interest of the learners but must be gradually reduced as the learner progresses in proficiency level. Also due to the multilingual nature of Nigeria facilitators are cautioned to be eclectic in their approach to the use of Code switch strategy.
\end{abstract}

Key words: Bilingualism, Code-switching, Mother tongue, Multilingual, Strategy

\section{Introduction}

The abysmal performance of students in public examinations in English Language as a subject in recent times and poor communication skills of literate people in our society has called for a reflection on the present teaching technique of the subject.

In a country with about four hundred languages Akindele and Adegbite (1999), English Language plays a vital role in the socio-economic, political and cultural lives of the people. It is a language that has performed the role of a lingual Franca to Nigerians and a language of unity to the over two hundred and fifty ethnic groups in the country. The need for at least a communicative competence level in English Language is thus expected for an average educated Nigerian. Although less than twenty-five percent of the Nigerian populace can be said to be proficient in English, it is the hope of every citizen to learn it in order to be in the mainstream of the country's political and socioeconomic system (Adegbite,1993). Bilingualism is a natural phenomenon of communication in Nigeria; hence a worthy Nigerian is essentially a bi-multilingual person who speaks his mother tongue primarily and the English Language secondarily.

Aside other ways of learning a foreign language, the formal classroom situation is the most visible form of learning English Language in Nigeria. Thus confirming Krashen's (1987) view that 'the role of the classroom is to bring a learner to a point where he can begin to use outside world for further second language acquisition'. In other words, the classroom is the base to gain comprehensible input that is now developed on the outside. As such facilitators of learning English Language in Nigeria are faced with many challenges and have to grapple with how best to teach Learners. One way of overcoming these challenges is for facilitators to switch languages; from English language to Mother tongue during teaching so as to attract the attention of learners to target language.

This paper will focus on the concept of Code Switching as a teaching strategy and its implication on the teaching and learning of second language in Nigeria.

\section{The Concept Of Code-Switching}

Code switching is regarded as a communicative phenomenon of constantly switching between two languages in a bilingual's speech repertoire. Akindele and Adegbite describe Code switching as a means of communication which involves a speaker alternating between one language and another in communicative events. Davy Crystal (1987) views the concept as a code switch when an individual who is bilingual alternates between two languages during his or her speech engagement with another bilingual. While Essien Okon (in Bangbose et al 1995) describes it as an alternate switch from one language to another. All these definitions infer that the speaker in a code-switching situation must have communicative competency in two languages for them to be able to switch from one language to another; it may be the mother tongue [MT] and a second language (L2), in the same discourse. In normal conversation between two bilinguals, code - switching consists of eighty-four percent single word switches, ten percent phrase switches and one percent clause switching (Skiba, 1997).

Code- switching perform various functions in its naturally occurring context. Speakers code switch to manipulate or influence or define situation as they wish, and to convey nuances of meaning and personal intention (Sert 2005). 
It is also used to build intimate interpersonal relationships among people who share the same code. It can be said to be a tool for creating linguistic solidarity especially between individuals who share the same ethno- cultural identity. And in some situations, it is used deliberately to exclude a person from a conversation. It is seen as a sign of solidarity within a group.

Other reasons may be the inability of a speaker to express himself / herself in one language so switches to the other to compensate for the deficiency. Examples of Code-switched Sentences in two Nigerian Languages of Yoruba and Igbo and English Languages include:

Yoruba/English

N'to ku t'e ma se nipe you will pour the solution into the beaker.

(The next process is to pour the solution into the beaker)

Make sure p'o fo moto yen kin to de

(Make sure you wash that car before I come)

Nkan to $\mathrm{n}$ se wa nipe we are not patriotic enough

(What is wrong with us is that we are not patriotic enough).

Igbo/English

Gbaa mbo hu m echi, so we can complete our discussion.

(Make sure you see me tomorrow so we can complete our discussion)

A sin a O kwuru ezi- okwu, I would have forgiven him

(If he had spoken the truth, I would have forgiven him)

\section{Code Switching In Language Learning}

Teachers' use of code switching has being a subject of controversy. It is not always performed consciously as such it is regarded as an automatic and unconscious behaviour. Nevertheless, it performs some basic functions. Teachers employ code switching strategy as a means of providing students with opportunities to communicate and enhance students understanding. It further helps to facilitate the flow of classroom instruction since the teachers do not have to spend so much time trying to explain to the learners or search for the simplest words to clarify any confusion that may arise. The teacher use code switching by starting the lesson in the English Language and may move into the second language and back. This ensures that the lesson is as communicative as possible. This approach allows teachers to balance the use of language within a given contact.

As teachers switch between codes students attention are gradually drawn to the objective of the teaching. Here code switching helps the learner to start from the "known to the unknown ". Situation of code switching in the classroom include topic switch, affective switch and repetitive switch (Sert 2005). Here a teacher can exploit students' previous L1 learning experience to increase their understanding of L2.

In topic switch, the teachers alter his or her language according to the topic being taught. This is mainly seen in grammar instructions where the teachers may want to introduce the discourse with a similar realisation in the first language. Affective functions are important in the expression of emotion, and building a relationship between the teacher and the student. In repetitive function, code switching is used to clarify the meaning of a word, and stress importance in the English language content for better comprehension. It also help student to become more competent in the language they are trying to learn. Here an instruction is given in English language and the teacher repeats same in the mother-tongue for the students. Teachers of science, technology and other allied disciplines will find Code switching very useful in explaining complex scientific terms, thus making the teaching and learning easy and interesting.

\section{Implications For Language Teaching And Learning.}

Code- switching is seen to be a useful tool in assisting English language teaching and learning process, especially at the foundation level where it is a skill being introduced to the pupils. It is also an opportunity for language development since it allows for effective transfer of ideas from the sender to the hearers. Exposure to code- switching at the early stages of learning enables learners to gain a head start towards effective and successful learning and gradually become proficient speakers of English language.

Code switching help learners to enjoy their learning due to their ability to comprehend the teachers input. The comprehensible input also allows them to feel less stressful and to become more comfortable to learn. Once they are comfortable with the environment, without any unnecessary anxiety the learners are able to focus and participate in classroom practice and activities more successfully. This psychological support makes learners feel more relaxed and comfortable to learn English language.

However, Code-switching has its negative effects in the teaching and learning of English language in Nigeria. When it is evident that the reason for switching language is due to inability of the teacher to express himself/herself in one language so switch to other language to compensate for the deficiency then there is the tendency to be passing a wrong message to the learners. The teacher is expected to inculcate the standard form 
of English language to the students by his own use of Standard English. However by his/her own use of code switching the primary objective of imparting Standard English into the learner is defeated.

A situation where a teacher gives an instruction or an idea in one language and repeats same in another language within the same period of time will slow down the rate of learning of the target language. Learners in this situation, having mastered this pattern of teaching may not take seriously to what is being taught since there is an assurance that the same message will be delivered in their mother tongue.

Cook (2002) is of the opinion that code switching in classes which do not share the same Mothertongue as we may have in many Nigerian classroom situations may create problems as some learners ( though may be few) will feel left out in the teaching process, thus creating psychological problems, as such defeating the objective of the learning process.

\section{Conclusion}

The function of Code switching has been highlighted in this paper with particular reference to its usefulness in a multilingual situation such as exist in Nigeria. The advantages and the negative effects of the use of code switching in the classroom situation are also discussed to clarify the phenomenon in different perspectives. We will therefore want to conclude that code switching should not be viewed in the light of an interference since it does not always serve as a detriment to proficiency in the learning of a language, but may be considered as a useful strategy in classroom interaction, if the aim is to make meaning clear and the transference of knowledge to students in efficient manner. However in the English language learning environment, the application of the code switching strategy should be minimal to ensure that teaching and learning of the target language- English language is given the prominence it requires.

\section{Reference}

[1] Akindele, F \& Adegbite, W (1999) The Sociology and Politics of English in Nigeria: An Introduction. Nigeria, Obafemi Awolowo University Press Ltd.

[2] Adegbite Wale, 'Towards an Efficient Bilingual Programme For Teaching Language Skills in Nigeria Primary Schools' Literary and Reading in Nigeria 6. 1993,337-351

[3] Badrul HishamA, Kamaruzaman Jusoff (2009) Teachers' Code Switching in Classroom Instruction for Low English Proficient Learners. Internet Retrieved www. Ccsenet.org/journal.htm/

[4] Krashen, S. D (1987) Principles and Practice in Second Language Acquisition. Hertfordshire, Prentice Hall International (UK) Ltd.

[5] Luisa Duran, Toward a Better Understanding of Code Switching and Interlanguage in Bilinguality: Implications for Bilingual Instructions. The Journal of Educational Issues of Language Minority Students, 14 1994, pp69-88

[6] Okon, E (1995) 'The English Language and Code- Mixing' (ed) Bamgbose et al New Englishes Ibadan, Mosuro Publishers.

[7] Skiba, R, Code Switching as a Countenance of Language Interference. The Internet TESL Journal, Vol.III, No10 1997. http://itesli.org/

[8] Sert, Olcay, The Functions of Code Switching in ELT Classroom: The Internet TESL Journal, Vol.XI No8.2005 http://itesli.org/

[9] Winifred E. Okereke, Code Switching and English Language in Nigeria: Implication for Communication. Journal of Women in Technical Education. Maiden Edition.2001.

[10] Cook, V. (2002) Portraits of the L2 User. Cleverdon: Multilingual Matters 